\title{
Effect of Epoxy-based Adhesives and Embedded Length in the Bond Strength of Post-installed Reinforcement in Concrete
}

\author{
S. O Ajamu ${ }^{1,2}$, O. D. Atoyebi ${ }^{2}$ and M. O. Oyeboade ${ }^{1}$ \\ ${ }^{1}$ Department of Civil Engineering, Ladoke Akintola University of Technology, Ogbomoso Oyo State Nigeria. \\ ${ }^{2}$ Department of Civil Engineering, Landmark University, Omu-Aran Kwara State Nigeria.
}

${ }^{2}$ ORCID: 0000-0001-9669-3179 (Atoyebi)

\begin{abstract}
In Nigerian building industry, there has been events in practice that required improving the structural integrity of existing structures: such as strengthening the interconnection between members. In cases where new structural members are to be added to the existing ones, instead of condemning the whole structure for demolition and rebuilding, post-installation process offers a remedial approach. However, the bond strength (BS) between the reinforcements and the concrete in the postinstalled structural element goes a long way to determine the anchorage and effectiveness of the whole structural system. In this study, the BS characteristics of post-installed reinforcement in concrete using four different locally available epoxy-based adhesives in Nigeria were examined. Compressive strength test on concrete cubes and pull-out test on post-installed concrete were carried out for embedment lengths of multiples of 10 and 15 of bar diameters used. Average compressive strength at 28 days was $23.91 \mathrm{~N} / \mathrm{mm}^{2}$ while the highest BS for $10 \mathrm{~d}$ and $15 \mathrm{~d}$ are respectively 5.52 and $6.80 \mathrm{~N} / \mathrm{mm}^{2}$ for $12 \mathrm{~mm}$ bar diameter while corresponding values are respectively 5.38 and $6.35 \mathrm{~N} / \mathrm{mm}^{2}$ for $16 \mathrm{~mm}$ bar diameter. From the results, it was observed that the pull-out force which is a measure of bond Stress is more influenced by the embedded length while increasing the embedment depth from $10 \mathrm{~d}$ to $15 \mathrm{~d}$ for the same bar size has less influence compared to increasing bar diameter. The epoxy-based adhesives possess appreciable BS characteristics for postinstalled reinforcement in concrete. However, of the three types of adhesives used, Hilti gave the highest BS capacity.
\end{abstract}

Keywords: Epoxy-based adhesives, Bond Strength, Compressive Strength, Pull-out Test, Retrofitting

\section{INTRODUCTION}

The basic requirement in the design of reinforced concrete structures is that the reinforcement must be adequately embedded into concrete to fully develop in the bar its yield stress when subjected to service or design loads [1,2]. In cases where storeys are built in stages, existing buildings extension or part of the structure needed to be strengthened to withstand design forces; structural elements are required to be added to an existing framework to enable structural continuity hence retrofitting. Post-installed reinforcements are needed to ensure the continuity of the structure, either with or without lap splice application in other to deal with flexure, shear, axial and torsional forces are dealt with successfully [3-5]. As more flexible and simple construction procedures are demanded in the rehabilitation and strengthening of existing concrete structures, post-installed adhesive or grouted anchors are gaining increasing importance [1,6]. Adhesive anchor is the insertion of reinforcing steel rod into cured concrete or masonry block by using a structural adhesive has bonding agent [7-11], holes are drilled into the hardened concrete to allow for postinstalled anchors to be placed at any desired position. Deteriorated concrete are rehabilitated and strengthened using anchors, it can also be used to attach structural elements to existing concrete structures. Adhesive anchors use the shallow depth to develop the required strength as compared to the normal development length, it differs to cast-in-place anchor in the load-transfer mechanism, the load is transferred along the anchor embedded portion through the adhesive depending on the concrete-adhesive bond and strength of adhesive-bar bond $[12,13]$. Tensile forces in the anchor can be effectively transferred into the surrounding mass by way of the bonding agent (i.e. adhesive or grout). Moreover, embedded anchors can further prevent or delay crack propagation and opening in hardened concrete. The efficiency of the load transfer mechanism strongly depends on the bond strengths of both the anchor-bonding agent and concrete-bonding agent interfaces [14]. Load transferred from the adhesive anchors to the concrete is done through mechanical interlock or chemical bonding, the bond between the adhesive-bar and adhesiveconcrete interface together with the extent to which the concrete surrounding the drilled hole is impregnated by the adhesive form the basis on which the load-transfer mechanism depends [12]. Reinforcement is inserted to carry tensile forces in flexure, shear, axial and torsion. Post-installed bars are generally used for the above outlined construction purposes though the theory of concrete behavior are mostly preferred due to flexibility of allowance in concrete attachment [15]. Retrofitting will ensure structures are restored to a required level of adequacy in terms of structural integrity. Adhesive anchors have been found to become significantly useful in retrofitting with the emergence of high strength bonding agents, this also allows for deflection and cracks control in existing structures through strengthening and stiffening [16]. The technique behind retrofitting involves the drilling of bars that have already been coated with adhesives into the correct position in the existing adjoining element in other to resist the imposed force. Laboratory pull out test on normal and high strength concrete was used to develop set of equations to from manufacturers tables for the design of chemically bonded postinstalled anchors, the tables were used alongside relevant codes $[17,18]$. Because this mode of construction is just coming into existence in the field of concrete, fewer designers still use large factor of safety or large numbers of anchorages and even make uses of few adhesives in the market. The determination of bond 
strength of post-installed reinforcement in concrete using various epoxy-based adhesives is an obvious prerequisite for the design and reliability of retrofit projects [12]. A new concrete element is expected to connect with existing structure with similarities in strength and stiffness hence the need for bonding-in or post-installing steel reinforcement [6]. Every manufacturer vouches for the good quality of his/her products through the product manuals, however, despite the widespread use of these epoxy-based adhesives, laboratory tests to verify their actual properties as claimed by their manufacturers is yet to be carried out. Therefore, to verify the properties of these products, this study focused on testing a variety of chemically bonded deformed (threaded) rebar anchors and to determine their pull out strength in concrete. It has been shown by confined pullout test that provided a suitable product is used and the installation is properly done, post-installed rebar behaves as cast-in-place rebar [19]. The adhesive is mechanically injected into the hole which is $4 \mathrm{~mm}$ larger than the rod diameter, the two reactive components are packaged in side-by-side cartridges. Epoxy adhesives are durable and long shelf life synthetic compound which contained curing agent and epoxy resin cross-linked together, it allows minimal shrinkage during curing [20,21]. Cook et al explained that the anchor and concrete are bonded together by a polymer matrix formed as a result of an exothermic reaction in the mixture of curing agent and the resin [22]. The bond characteristics and strength of post-installed adhesive are dependent on different factors like the concrete properties, adhesive properties, fiber material strength and modulus of elasticity, mechanical properties of reinforcing bars etc. [14]. Several studies and investigations have been made by various researchers towards investigating the bond strength characteristics of post-installed reinforced concrete using epoxy-based adhesives: Ehab and Brahim studied the behaviour GFRP post-Installed Adhesive Anchors using sand coated GFRP V-ROD bars driven into plain concrete using epoxy-based adhesives with different embedment lengths as a function of the bar diameters (i.e. 5, 10 and 15 times the bar diameter, d) [23,24]. The two types of epoxy-based adhesives used include; Type HIT RE 500, Type HIT 150. Their results indicated that there is no significant difference in the bond strength capacity and mode of failure between the anchors with $10 \mathrm{~d}$ and $15 \mathrm{~d}$ embedment lengths for most of the tested specimen. Tayeh et al [25] studied the pull out behavior of post-installed rebar connections using chemical adhesives (Sikadure-31CF and EPICHOR 1786) and cementbased adhesives (ultra-high performance self-compacting concrete (UHPCC)). Their results showed that the use of the adhesives and UHPCC pull out load values were close while they outperformed mortar bonded (grouted) specimens. In this study, bond strength characteristics of post-installed reinforcement in concrete using using locally available HIT 500, Araldite and 4 minutes as epoxy-based adhesives to determine the bond strength capacity and failure modes with $10 \mathrm{~d}$ and $15 \mathrm{~d}$ embedment length were investigated.

\section{MATERIALS AND METHODS}

The materials used in this study include Epoxy-based adhesives, ribbed bars, Ordinary Portland Cement, granite, sharp sand and water. Three different commercial adhesives were used to glue the anchors to the concrete. The first one is called HIT RE 500 (Adhesive TYPE I) which is an epoxy-based adhesive with a high strength specifically designed to fasten in solid based materials. The second is Araldite (adhesive TYPE II), a slow curing adhesive that has a wide range of application including sealing up ceramics, metals etc. The third is Four minutes (adhesive TYPE III), a rapid curing adhesive that has a wide range of application including sealingup ceramics, metals etc. These three types of adhesives used as shown in Figure 1 were selected based on availability in Nigeria. Two different ribbed bar diameters of $12 \mathrm{~mm}$ and $16 \mathrm{~mm}$ were used in this study and were of tensile strengths of $383 \mathrm{~N} / \mathrm{mm}^{2}$ and $390 \mathrm{~N} / \mathrm{mm}^{2}$ respectively.

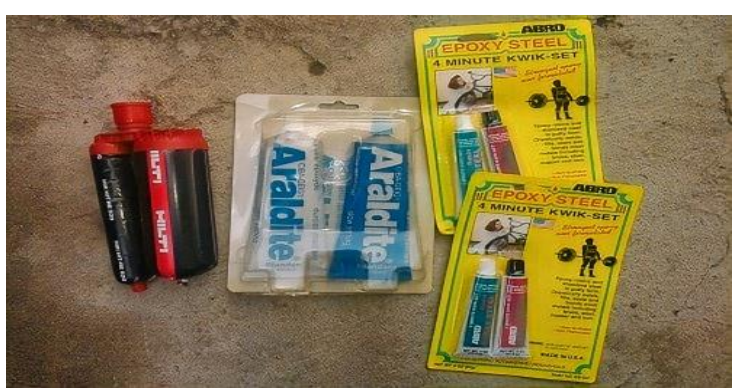

Figure 1: Types of Adhesive used: HIT 500, Aradilte and 4 minutes

The samples were taken for particle size distribution test following the procedures described in clause 5 of BS 812103.1:1985 [26]. The samples were air-dried before weighing and sieving.

\section{II.I Production of Concrete Cubes and Cylinders}

The production of fresh concrete involved batching and mixing processes with the materials measured by weight for a mix ratio of $1: 1 \frac{1}{2}: 3$ and the water-cement ratio of 0.5 . The sharp sand, cement and granite were mixed on an impermeable surface which wase scrapped, brushed and swept to make the surface free from materials that could alter the properties of the mix. Concrete cubes and cylinders were produced from the fresh concrete to carry out the compressive strength test and the pullout tests respectively. The concrete cubes were produced using cube mould of $150 \times 150 \times 150 \mathrm{~mm}$ and cylindrical moulds of $100 \mathrm{~mm}$ diameter by $200 \mathrm{~mm}$ height and $150 \mathrm{~mm}$ diameter by $300 \mathrm{~mm}$ height to accommodate the different embedment lengths of rebars during the pull-out tests. The steel cylinder used was free of all impurities by washing and oiled in order to enhance ease of removing the mold when the concrete is set. The wet mixture was filled into the mould in layers with each layer being compacted with a ribbed bar on a rigid and levelled platform. The excess mixture on the sides and surface of the cylinder were scraped off and then levelled using a straight edge. The concrete cubes and cylinders were cured for 28days.

\section{II.II Compressive strength test}

The compressive strength test was carried out on cured concrete cubes under the provisions of BS EN 12390-3:2002 [27]. Specimens were loaded to failure in a compression testing 
machine conforming to EN 12390-4:2000 specifications (Figure 2)[28]. The maximum load sustained by the specimen was recorded and the average compressive strength of the concrete was calculated for each of the curing days.

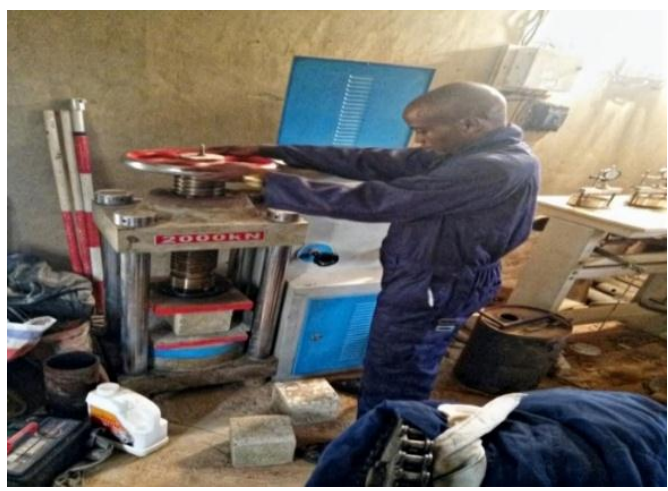

Fig. 2: Compressive strength test machine

\section{II.III Pull-out Test on Post-installed Reinforcements in Concrete cylinders using Epoxy-based Adhesives}

The pull-out test was carried out on post-installed reinforcements in concrete cylinders at 28 days of curing. The depths of embedment of the reinforcements were varied in multiples of the bar diameters i.e. $10 \mathrm{~d}$ and $15 \mathrm{~d}$. Two different bar sizes; $12 \mathrm{~mm}$ and $16 \mathrm{~mm}$ were used for post-installed reinforcement. The diameter of holes drilled at the centres of the concrete cylinders (Figure $3 \mathrm{a}$ and $3 \mathrm{~b}$ ) were $4 \mathrm{~mm}$ greater than the bar sizes installed.

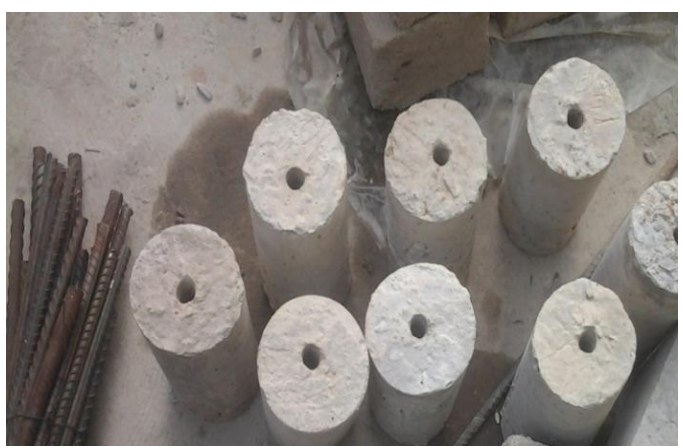

Figure 3a: Holes drilled in concrete cylinders

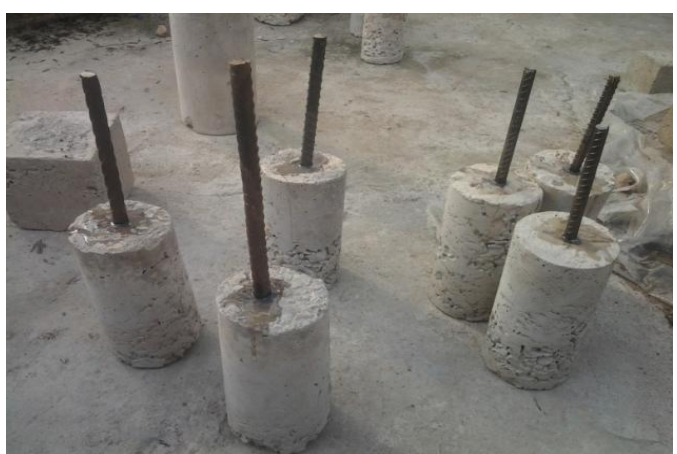

Figure 3b: Reinforcements installed using epoxy-based adhesives as binding agents.
Concrete cylinders were used for this test instead of concrete cubes because the cube size is limited to $150 \mathrm{~mm}$ and its easier to hold the concrete cylinders in the test machine than to hold cubes for the pull-out test. A universal testing machine was used to perform the pull out tests on the post-installed reinforcements in concrete cylinders. The results of the test were obtained as a printout from the digital display component of the machine. The test was carried out in accordance with the provisions of BS 1881 Part 116:1983 [29]. The bond strength was calculated for each type of adhesive material and embedded length, the values obtained were compared with the minimum standard specifications in Table C1.2 of European Technical Approval manual for good bonding conditions for diamond drilling method (wet cutting system) [30].

\section{RESULTS AND DISCUSSION}

\section{III.I Particle size distribution of aggregates used}

Sieve analysis was used to characterize the fine and the coarse aggregates used. The results of the sieve analysis test performed on the fine aggregate (sand) are as presented in Figure 5a. The fineness modulus was obtained by dividing the percentage cumulative of mass retained by 100 (2.85). This shows that sand is medium size according to Unified Soil Classification System (USCS). The values of d10, d30 and d60 were obtained as $0.25 \mathrm{~mm}, 0.48 \mathrm{~mm}$ and $0.90 \mathrm{~mm}$ respectively. The result shows that the fine sand used was well-graded according to calculations in equations 1 and 2

$$
\begin{gathered}
C_{u}=\frac{D_{60}}{D_{10}}=\frac{0.9}{0.25} \approx 4(\text { well graded }) \\
C_{c}=\frac{\left(D_{30}\right)^{2}}{D_{60} x D_{10}}=\frac{0.48^{2}}{0.9 \times 0.25} \approx 1 \\
\quad(\text { well graded })
\end{gathered}
$$

The results show that sand is well-graded as recommended by the Unified Soil Classification System (USCS) given that for coefficient of Uniformity, $\mathrm{Cu}$, value must be less than or equal to 6 and for the coefficient of curvature, $\mathrm{Cc}$, the value must be greater than 1 but less than 3 . The results of sieve analysis test performed on the coarse aggregate (granite) reveal values of $\mathrm{d} 10, \mathrm{~d} 30$ and $\mathrm{d} 60$ are obtained as $16 \mathrm{~mm}, 22 \mathrm{~mm}$ and $28 \mathrm{~mm}$ respectively (Figure $5 \mathrm{~b}$ ) which shows that the coarse aggregate used was uniformly graded according to calculations in equations 3 and 4 .

$$
\begin{gathered}
C_{u}=\frac{D_{60}}{D_{10}}=\frac{28}{16}=1.75<4 \\
\text { (uniformly graded) } \\
C_{c}=\frac{\left(D_{30}\right)^{2}}{D_{60} x D_{10}}=\frac{22^{2}}{28 \times 16}=1.08<1 \\
\text { (uniformly graded) }
\end{gathered}
$$




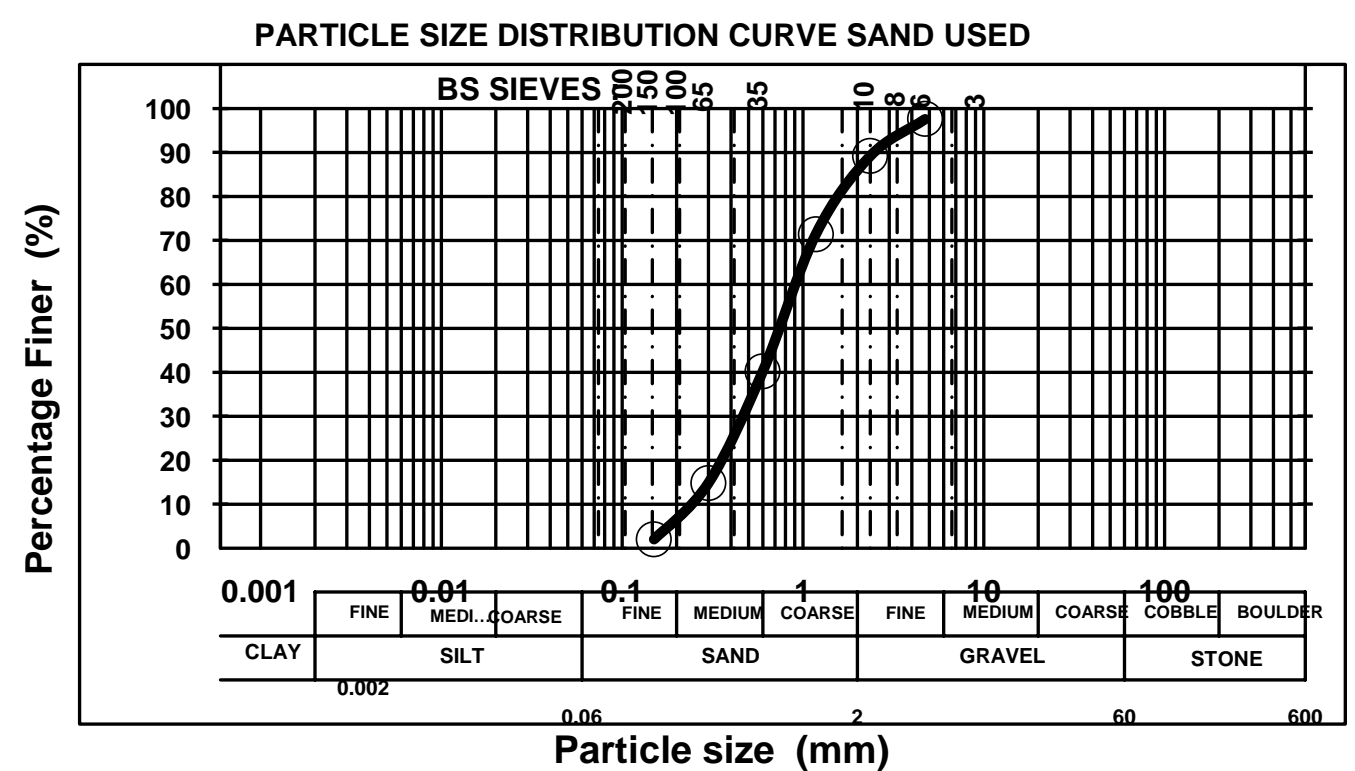

Figure 5a: Particle Size Distribution Chart for sand used

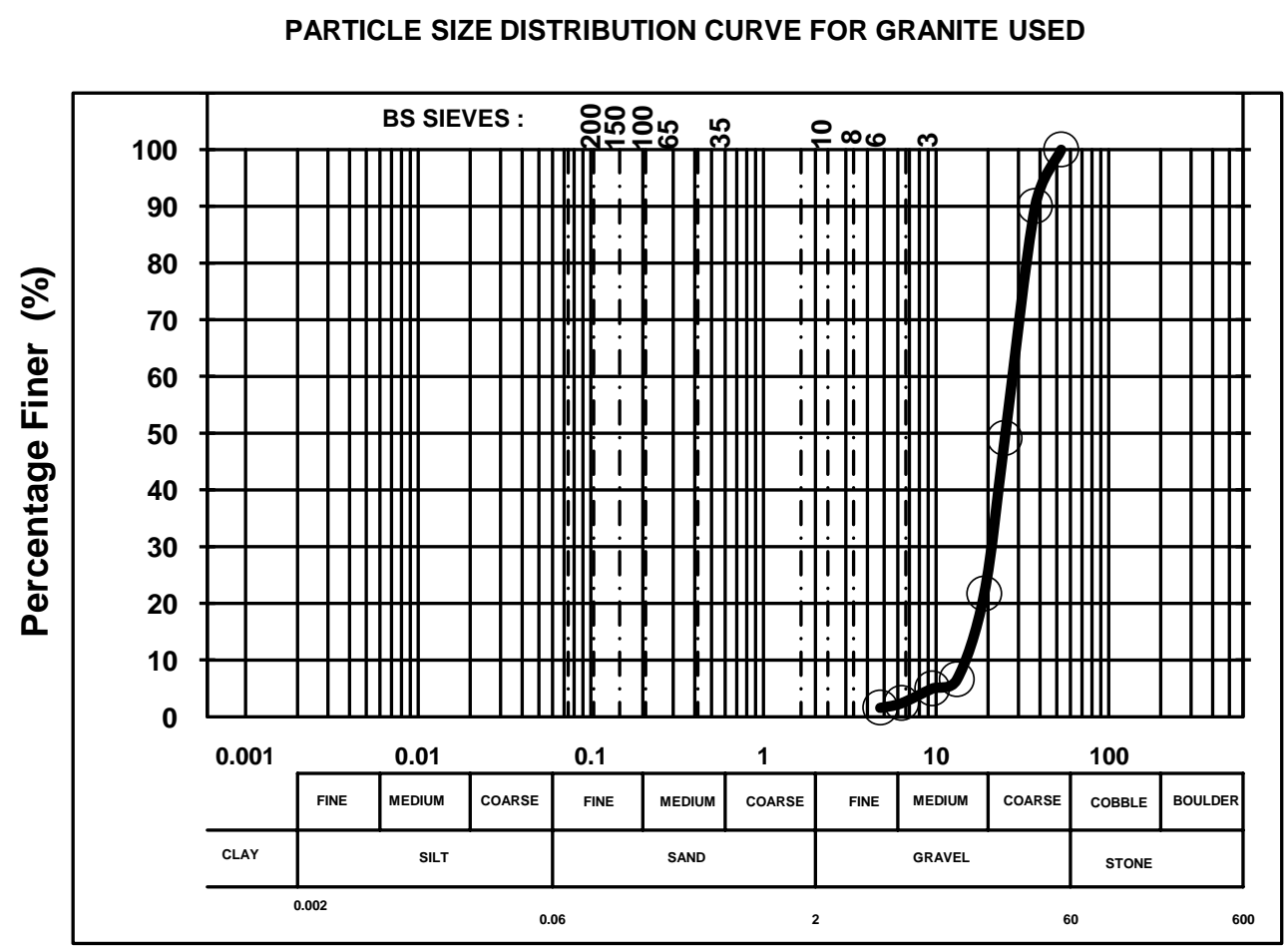

Particle size (mm)

Figure 5b: Particle Size distribution Chart for coarse aggregates used

\section{III.II Compressive strength test on concrete cubes}

The result of the compressive strength tests on concrete cubes at curing ages of 7, 14, 21 and 28 days are as presented in Table 1 which show the variation of average compressive strength of concrete produced with increase in curing time in days.

The results reveal that the compressive strength increased gradually from $16.04 \mathrm{~N} / \mathrm{mm} 2$ at 7 days of curing to $23.9 \mathrm{~N} / \mathrm{mm} 2$ at 28days. 
International Journal of Engineering Research and Technology. ISSN 0974-3154 Vol.13, No.3 (2020), pp. 477-483

(C) International Research Publication House. https://dx.doi.org/10.37624/IJERT/13.3.2020.477-483

Table 1: Compressive Strength for Concrete at different curing days

\begin{tabular}{ccc}
\hline Curing Days & $\begin{array}{c}\text { Average Crushing } \\
\text { load }(\mathrm{kN})\end{array}$ & $\begin{array}{c}\text { Average Compressive } \\
\text { Strength }\left(\mathrm{N} / \mathrm{mm}^{2}\right)\end{array}$ \\
\hline 7 & 360.94 & 16.04 \\
14 & 403.41 & 17.93 \\
21 & 470.25 & 20.9 \\
28 & 537.82 & 23.9 \\
\hline
\end{tabular}

\section{III.III Pull - Out Test}

The results of the pullout test performed on each type of adhesives at two different embedded length for the two bar sizes selected are as presented in Figure 3. No cone failure was observed in any of the pull-out tests conducted on 4minutes and few cone failure were noticed in Hilti and Araldite at a lower embedded depth of 10d. Pull through failure mode was noticed in all the 4minutes samples tested without any crack observed on the concrete (Figure 9a) while the adhesive/concrete interface failures were noticed in the Hilti and Araldite at a high embedded length of 15d (Figure 9b). The most commonly observed is the adhesive/concrete interface failures which were as a result of a stronger bond between the adhesives and bar, this was also common with higher embedded lengths. The bar/coating surface failure was predominant when Araldite was used, this was as a result the presence of more bonding strength between the concrete and the adhesives than it was between the adhessive and the bar.

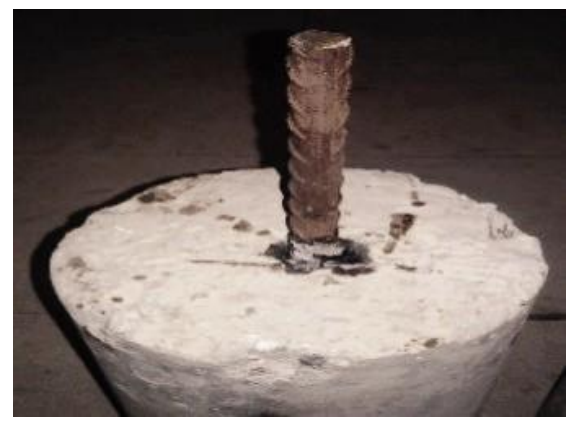

Figure 9a: Pull through failure mode

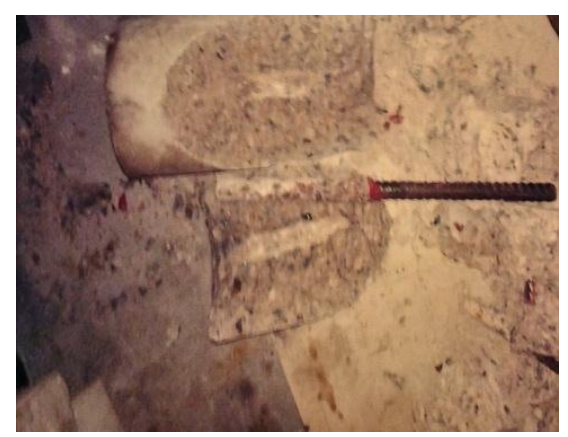

Figure 9b: Adhesive/concrete interface

\section{III.III.I Calculation of the pull-out strength $\sigma_{p}$}

Pull-out force $=$ Surface area of embedded rod $\mathrm{x}$ bond strength

$$
\begin{aligned}
& \mathrm{F}_{\mathrm{u}}=\pi \mathrm{DL} \boldsymbol{\tau} \\
& \boldsymbol{\tau}=\frac{F_{u}}{\pi D L}
\end{aligned}
$$

Table 2 shows the results of the pull-out test for $12 \mathrm{~mm}$ diameter bar for varying embedment lengths (10d and 15d) while Table 3 shows the corresponding results for $16 \mathrm{~mm}$ diameter bar.

Table 2: Test Results for $12 \mathrm{~mm}$ Diameter bar for $10 \mathrm{~d}$ and $15 \mathrm{~d}$ embedment lengths

\begin{tabular}{cccc}
\hline $\begin{array}{c}\text { Adhesive } \\
\text { type }\end{array}$ & $\begin{array}{c}\text { Embedded } \\
\text { length L, } \\
(\mathrm{mm})\end{array}$ & $\begin{array}{c}\text { Average } \\
\text { pull-out } \\
\text { Load, Fu } \\
(\mathrm{kN})\end{array}$ & $\begin{array}{c}\text { Bond stress } \tau, \\
\left(\mathrm{N} / \mathrm{mm}^{2}\right)\end{array}$ \\
\hline Araldite & $10 \mathrm{~d}$ & 9.01 & 2.00 \\
& $15 \mathrm{~d}$ & 15.99 & 2.35 \\
4minutes & $10 \mathrm{~d}$ & 20.19 & 4.45 \\
& $15 \mathrm{~d}$ & 22.01 & 3.23 \\
Hilti & $10 \mathrm{~d}$ & 24.99 & 5.52 \\
& $15 \mathrm{~d}$ & 46.01 & 6.80 \\
\hline
\end{tabular}

Table 3: Test Results for $16 \mathrm{~mm}$ Diameter bar for $10 \mathrm{~d}$ and $15 \mathrm{~d}$ embedment lengths

\begin{tabular}{lccc}
\hline $\begin{array}{l}\text { Adhesive } \\
\text { type }\end{array}$ & $\begin{array}{c}\text { Embedded } \\
\text { length L, } \\
(\mathrm{mm})\end{array}$ & $\begin{array}{c}\text { Average pull- } \\
\text { out Load, Fu } \\
(\mathrm{kN})\end{array}$ & $\begin{array}{c}\text { Bond stress } \tau, \\
\left(\mathrm{N} / \mathrm{mm}^{2}\right)\end{array}$ \\
\hline Araldite & 10d & 21.99 & 2.75 \\
4minutes & $15 \mathrm{~d}$ & 37.49 & 3.1 \\
& $10 \mathrm{~d}$ & 20.19 & 4.45 \\
Hilti & $15 \mathrm{~d}$ & 37.09 & 3.08 \\
& $10 \mathrm{~d}$ & 50.95 & 6.35 \\
& $15 \mathrm{~d}$ & 64.99 & 5.38 \\
\hline
\end{tabular}

Tables 2 and Table 3 compare the bond stress of the adhesives used. The bond stress was calculated using equation 6 , the result depicts how well bonded was the post-installation. Using Hilti gave better results when compared to the other two epoxy adhesive i.e. Araldite and 4 minutes. The bond stress of Araldite at $10 \mathrm{~d}$ was low $(2.00 \mathrm{~N} / \mathrm{mm} 2)$ and did not meet the minimum requirement set out in Table $\mathrm{C} 1.2$ of European Technical Approval manual for good bonding conditions [30] for diamond drilling method (wet cutting system), for $12 \mathrm{~mm}$ bar the value should not less than $2.3 \mathrm{~N} / \mathrm{mm} 2$ and for Araldite to be used with $12 \mathrm{~mm}$ bar, a minimum of $15 \mathrm{~d}$ embedded length will be required. The corresponding value recorded for 4 minutes and Hilti were greater than $2.3 \mathrm{~N} / \mathrm{mm} 2$ which is the minimum 
required for grade $\mathrm{C} 20 / 25$ concrete. However, for $16 \mathrm{~mm}$ bar and with $10 \mathrm{~d}$ and $15 \mathrm{~d}$ embedded lengths all the adhesive materials used satisfied the minimum requirement of bond strength of $2.3 \mathrm{~N} / \mathrm{mm} 2$. Generally, Araldite gave the least bond stress compared to 4minutes and Hilti both for all parameters used, Hilti gave the highest bond stress in all.

\section{CONCLUSION}

The following conclusion are made from this study:

(i) Hilti adhesive gave the highest bond stress while Araldite gave the lowest for all the different embedment lengths bar diameters used.

(ii) The average ultimate load increased by increasing the embedment depth. However, increasing the embedment depth from 10d to $15 \mathrm{~d}$ has less effect as the bar diameter increases. Hence the pull out force is more influenced by the embedded length than the bar diameter.

(iii) Increasing the embedment depth leads to bond stress increment in some cases and which does not agree with some previous findings for steel bars.

\section{RECOMMENDATIONS}

The following are the recommendations based on the research finding:

i. 4minutes and Araldite can be used for retrofitting works.

ii. When $12 \mathrm{~mm}$ diameter bar is to be used in retrofitting or post-installing of reinforcement, $15 \mathrm{~d}$ embedment length should be used with Araldite as adhesive.

\section{REFERENCES}

[1] C.E. Reynolds, J.C. Steedman, Reinforced Concrete Designer's Handbook, edition., London., 10th ed., E \& FN Spon, Taylor \& Francis Group, London, UK, 2008.

[2] I. Boumakis, M. Marcon, L. Czernuschka, R. Wanwendner, Concrete creep and shrinkage effect in adhesive anchors subjected to sustained loads, Eng. Sci. $175 \quad$ (2018) 790-805. doi:10.1016/j.engstruct.2018.07.067.

[3] T.F. Awolusi, O.L. Oke, O.O. Akinkurolere, O.D. Atoyebi, Comparison of response surface methodology and hybrid-training approach of artificial neural network in modelling the properties of concrete containing steel fibre extracted from waste tyres, Cogent Eng. 6 (2019) 1-18. doi:10.1080/23311916.2019.1649852.

[4] J. Shi, W. Cao, Z. Wu, Effect of adhesive properties on the bond behaviour of externally bonded FRP-toconcrete joints, Compos. Part B. 177 (2019) 107365. doi:10.1016/j.compositesb.2019.107365.

[5] O.D. Atoyebi, J.O. Afolayan, A. Chinwuba, Analyses and Interpretations of Structural Health Monitoring Data on Reinforced Concrete Buildings: A Critical
Review, J. Eng. Appl. Sci. 14 (2019) 9657-9666.

[6] B.S. Hamad, R.A. Hammoud, J. Kunz, Evaluation of Bond Strength of Bonded-In or Post-Installed Reinforcement, ACI Struct. J. 103 (2006) 207-218.

[7] R.A. Cook, J. Kunz, W. Fuchs, R.C. Konz, Behavior and Design of Single Adhesive Anchors under Tensile Load in Uncracked Concrete, ACI Struct. J. 95 (1998) 9-26.

[8] L. Ke, C. Li, N. Luo, J. He, Y. Jiao, Y. Liu, Enhanced comprehensive performance of bonding interface between CFRP and steel by a novel film adhesive, 229 (2019). doi:10.1016/j.compstruct.2019.111393.

[9] M. Liu, M. Dawood, Experimental study and probabilistic bond strengths of adhesively-bonded steel butt joints under mixed-mode loadings, Eng. Struct. 172 (2018) 163-171. doi:10.1016/j.engstruct.2018.05.111.

[10] C. Li, L. Ke, J. He, Z. Chen, Y. Jiao, Effects of mechanical properties of adhesive and CFRP on the bond behavior in CFRP-strengthened steel structures, Compos. Struct. $211 \quad$ (2019) 163-174. doi:10.1016/j.compstruct.2018.12.020.

[11] S. Wang, Y. Li, Y. Guo, B. Cai, G. Zhang, Z. Liu, P. Wang, Development of a two-component structural adhesive for bonding of metals and polymeric composites, Int. J. Adhes. Adhes. 90 (2019) 38-46. doi:10.1016/j.ijadhadh.2019.01.018.

[12] R.A. Cook, Load-deflection behaviour of cast-in-place and retrofit concrete anchors, ACI Struct. J. (1992) 639-649.

[13] B. Hooi, B. Hyun, S. Seo, J. Kim, J. An, H. Youn, Waterproofing performance of waterstop with adhesive bonding used at joints of underground concrete structures, Constr. Build. Mater. 221 (2019) 491-500. doi:10.1016/j.conbuildmat.2019.06.103.

[14] Y.C. Wang, P.M.H. Wong, V. Kodur, An experimental study of the mechanical properties of fibre reinforced polymer (FRP) and steel reinforcing bars at elevated temperatures, Compos. Struct. 80 (2007) 131-140.

[15] R.A. Cook, G.T. Doerr, R.E. Klinge, Bond stress model for design of adhesive anchors, ACI Struct. J. 90 (1993) 514-524.

[16] R.A. Barnes, G.C. Mays, The transfer of stress through a steel to concrete adhesive bond, Int. J. Adhes. Adhes. 21 (2001) 495-502. doi:https://doi.org/10.1016/S01437496(01)00031-8.

[17] ACI Committee 308, ACI 308 . 1-98 Standard Specification for Curing Concrete, 1998.

[18] EN1992, EN 1992- Eurocode 2: Design of concrete structures - Part 1: General rules and rules for buildings, 2001.

[19] H.A. Spieth, J. Ozbolt, R. Eligehausen, Numerical and Experimental Analysis of Post-installed Rebars Spliced with Cast-in-Place Rebars, in: Int. Symp. Connect. between Steel Concr., RILEM Publications, Stuttgart, 2001: p. 889. 
International Journal of Engineering Research and Technology. ISSN 0974-3154 Vol.13, No.3 (2020), pp. 477-483

(C) International Research Publication House. https://dx.doi.org/10.37624/IJERT/13.3.2020.477-483

[20] S. Ahnaf, A. Sinha, Q. Zhang, J. Tatar, Hygrothermal conditioning of wet-layup CFRP-concrete adhesive joints modified with silane coupling agent and coreshell rubber nanoparticles, Constr. Build. Mater. 227 (2019)

116531. doi:10.1016/j.conbuildmat.2019.07.257.

[21] P. Long, X. Hong, E. Ferrier, Elevated temperature thermomechanical behaviour of near surface mounted CFRP reinforced concrete specimens : Effect of adhesive at concrete/CFRP interface, Eng. Struct. 197 (2019) 109361. doi:10.1016/j.engstruct.2019.109361.

[22] R.A. Cook, R.C. Kunz, Factors influencing bond strength of adhesive anchors, ACI Struct. J. 98 (2001) 76-86.

[23] E.A. Ahmed, E. El-salakawy, B. Benmokrane, Behaviour of Post-Installed GFRP Adhesive Anchors in Concrete, Quebec, Canada, 2006.

[24] E.A. Ahmed, E.F. El-Salakawy, B. Benmokrane, Bond Characteristics of GFRP Adhesive Anchors, in: Third Int. Conf. FRP Compos. Civ. Eng. (CICE 2006), Miami, Florida, USA., 2006.

[25] B.A. Tayeh, Z.M. EL dada, S. Shihada, M.O. Yusuf, Pull-out behavior of post installed rebar connections using chemical adhesives and cement based binders, J. King Saud Univ. - Eng. Sci. (2017). doi:https://doi.org/10.1016/j.jksues.2017.11.005.
[26] BS 812-103.1:1, Testing aggregates - Part 103: Methods for determination of particle size distribution - Section 103.1 Sieve Tests., 2004.

[27] BS EN12390-3:2000, British Standard Testing hardened concrete Part 3: Compressive strength of test specimens, UK, 2003.

[28] BS EN12390-4:2000, British Standard Testing Hardened Concrete (Part 4) - Compression strength: Specification of test machines, UK, 2009.

[29] BS1881-116:1983, BS 1881 Part 116-1983. Testing Concrete: Method for determination of compressive strength of cubes, (1983).

[30] ETA-Manual, Design values of the ultimate bond resistance fbd according to EN 1992-1-1 for diamond drilling method (wet cutting system). European Technical Approval manual for good bonding conditions, 2015. 